Pakistan Journal of Education

Vol.36, No.2, 2019, 115-135

\title{
Innovative Teaching: An Effective Ingredient for Educational Change at University Level
}

\author{
Farah Naz \\ Hasan Sohaib Murad ${ }^{\dagger}$
}

\begin{abstract}
Educational change is inexorable for societal growth. Education and its demands are changing every day. Educational change in higher education institutions gravely needs an effective and innovative teaching methodology inside and outside classrooms. It is voice of the time, the innovative methods in teaching can not only meet the individual needs of the students but can produce high quality future professionals. To review the current status of teaching in universities, a quantitative study has been conducted. A survey based on innovative teaching practices and educational change linked with these practices have been done from the sample of 400 students of BS / MPhil / PhD and 200 teachers of BS/ MPhil $/ \mathrm{PhD}$ level. The results have shown that still there's a long way to go to encounter the fast changing scenario of education at higher level. Majority of the higher education teachers are accepting change but at the same time, they are more comfortable with the conventional teaching methods. The results are also found to be insignificant for top management involvement in the process of change.
\end{abstract}

Keywords: educational change, innovative teaching, ingredient, university level

\footnotetext{
* University of Management and Technology, Lahore. Email: farah454@hotmail.com † Deceased, DoD $10^{\text {th }}$ September 2018

Supervisor University of Management and Technology, Lahore
} 


\section{Introduction}

Education has always played a vital role in the growth and development of a society. No generation can survive or flourish without bringing a positive change in their behaviors, which is the nerve of education. Edification is a permanent course of development that starts with one's birth and stops with his death (Ballantine, Hammack, \& Stuber, 2017). Education has to be broad, imperishable, upgraded and modern according to the need of time, and must be improving continuously for future perspectives. Collins and Halverson (2018), said that the face of education is thoroughly changing every day due to the stormy development in the technologies, which has a great effect on learning of students outside the institutions.

Many different perspectives are prevailing, regarding change. But, there are few extents of change on which everyone has an agreement. According to Robbins and De Cenzo (2001), modification in the institutional culture, human resource, and technical facilities is change. Change in education is embedded in altering beliefs, novel ways of transmission of knowledge (Carnoy \& Rhoten, 2002). Or it may be defined as the acceptance of innovation (Carlopio, 1998), method of up gradation(Bell \& Ritchie, 1999), procedure of erudition of new concepts and thoughts (Fullan, 2001).

It's very important, nowadays, in this rapidly changing world that we produce qualified and skilled professionals who are fully ready to handle the challenges of future and capable to turn out well. With the fast growth of world thrift, the responsibility of university has also changed. The role of higher education institutions has increased in the economy of any country (Fadeeva \& Mochizuki, 2010; Nobes, Parker, \& Parker, 2008).Therefore, it is the time that the policy makers and education leaders must start reconsidering the education system in or out of the organizations to meet the pace of educational change. But, this progression in education system must be methodical, persistent, and measureable. This can happen if all the stakeholders who are leading education and responsible for implementing the innovative practices target the process of Teaching/ Learning (TL).

\section{Literature Review}

Education requires radical change that give blue ribbon learning results. To get this, the main focal point to work on is practices and TL theories (Serdyukov, 2017).Teachers, students and all others who are involve in the learning process make a community. This partnership is 
construe byHealey, Flint, and Harrington (2016), as ties between scholars, tutors, education facilitators, and administration who are sincerely involved to gain maximum from the process of learning. Learners learn the best when they realize that they are an active part of a collegiate or scholarly association. Similarly, the tutors feel satisfied and rewarded when they have this impression that their work has a positive impact and is creating a change. This inner inspiration is the fundamental component of learning. As Wlodkowski and Ginsberg (2017) in their book called motivation the basic component of survival that gives the vigor and right course towards human behavior.

Universities need to work on the sense of learning ownership and commitment of students and teachers. If they do this diligently, the institutions can become a vivacious and interesting place for both facilitators and learners. It is important to engage senior management/ leadership also to ensure the continuity of these communities (Reaburn \& McDonald, 2017). By doing this students will not only become the academic companions, but the partners in innovative teaching process. Matthews, Cook-Sather, and Healey (2018), said companionship between instructor and learner transforms the culture of institution in which the students are the active partner in building knowledge in the lecture room and involved in struggle to improve and innovate the education. Students' ownership for their learning and realizing themselves as the partner of scholarly association will improve their well- being and capability to succeed (their transformation). As said by Kegan (2018), this type of education is more than a simple theoretical change in behavior or an increment in account of knowledge, it's a change in epistemology.

This Teaching Learning method should focus on 4 major areas;

1. Curriculum is to be revisited and expanded to absorb innovative student centered activities, teachers' involvement and real world learning tasks. To relate higher education with the fast and continuous progression, the curriculum needs creative concepts and methods to integrate information, abilities, practice and inner drive (Cincera et al., 2018).

2. Teaching methods are required to be changed from conventional into more co-operative and collaborative ones. The futuristic pedagogical practices are required to be adopted. This change in the teaching is unavoidable due to quick alteration in culture and new formation of societies, available information, technology, and students' decreasing interest in conventional lecture method (Evers, Brouwers, \& Tomic, 
2002). Myers (2017), said that the change in education relies on the fact that teachers perceive and act.

3. It is a global world. Now almost every higher education institution has diverse classrooms. Inclusive education is the talk of town. This situation also demands use of innovative teaching methods instead of traditional ways of teaching. A comprehensive education system needs an efficient change in current practices (Gargiulo \& Metcalf, 2017). For this, the educational organizations needs to adapt various innovative technologies and teaching methods to accommodate the diverse population of students (Hamburg \& Bucksch, 2017).

4. Finally, inclusion of ICT in every process of education to meet present and future educational change. Best results can only be obtained in higher education through integrating technology in our TL processes (Bates \& Poole, 2003).

Today's fast track transformations (Schwab, 2017) in every walk of life is putting lot of pressure on apprentices and responsibility on higher education. Wards must be prepared to think critically and bring creative solutions to the problems, have strong drive to face the future challenges, and well- furnished to take the position of a leader. Which means higher education is something far ahead than educational gain in one field as other behavioral skill and high order thinking are getting more importance. A proficient professional or expert usually shows more in their practice which is implicit. They have the capacity to handle exceptional, ambiguous and differed practical circumstances $(H$. Bowen, 2018; Schön, 2017). In today's modern societies, as the knowledge and realities are thriving in every coming day, the skills; crossways investigation, analytical evaluation, distillation, and meaningful communication have become the vital features of achievement. The higher education bodies are committed to sustainability. They are taking initiatives for internalization of education (Lozano et al., 2015).

Shift in the paradigm of teaching is becoming the most significant component of the $21^{\text {st }}$ century tertiary education. It has moved forward from teachers' transference of knowledge and its detention with students. Now,it's about transforming the graduates into skilled professionals. University teachers have to train the students to behave as specialists, have skill to understand the problem, think analytically to give novel vision, and their wisdom be beneficial for the community and humanity. It has become compulsory for the educators to develop selfdirected apprentices who understand that knowledgeand development are the critical components for communal, intellectual, responsive, and somatic growth (Betts, Kapushion, \& Carey, 2016). In the result of this 
shift, university education is moving towards an innovative, different and provocative era. Quality higher education organizations are aware of the fact that need to focus their instructional mode from information providing lecture technique to collaborative one. Teachers' teaching activities alone cannot produce the required results. Tutors individual philosophies, insight of content, and personal competence are important factor behind the motivation of a teacher to take up creative approaches for leaning that can create an influential impact in refining learning outcomes (Muijs \& Reynolds, 2017). Their teaching objective should be promoting long lasting abilities like; creative and critical thinking, evolving skilled demeanor, and inquisitive mind set (Culp, 2016).

Students are an equal partner of their learning in conjunct method of instruction. It allows the learner to learn through inquiry, creativity, and mistakes. This is the best way to teach them judge and perform like a skilled professional and have an improved view of skilled self (Holmes, Wieman, \& Bonn, 2015). Researches have proved that dynamic study methods increase the efficacy of coaching and tutoring (Freeman et al., 2014) and enhance the conceptual understanding of scholars. Shift to interactive teaching, saidTalbot, Doughty, Nasim, Hartley and Le (2016), will involve them in the interrogation of knowledge in so many different ways like; searching answers electronically, discussing the problem with peers, adaptive teaching, and other modern methods of learning.

Managing the change is the main action in recognizing the institutional aim. Whereas the practical employment of change is called innovation. We may say that the enduring process of change is bringing innovation. Improvement in education through the process of innovation is relied on the milieu of social structure, relations between them, and dependence of all levels on each other (Christensen, Raynor, \& McDonald, 2016).

The change in education is dependent on how teachers perceive and act. It's simple as well as complex at the same time. The changes that teachers are facing now a days commencing and executing may differ from region to region, but they incorporate more or less the same larger topographies (Hargreaves, Lieberman, Fullan, \& Hopkins, 2014). They are always required to involve in educational change through incorporating innovations.

\section{Objective of the Study}

If we look into past, any improvement is due to transformation and newness. Every learning organization is under constant requirement 
of change and advancement through modernization. The change in education sector is mostly considered to be quite challenging, not because of the consideration of change but due to the wisdom, abilities, and mindset of those who are facilitator and implementers of this change. Reconstruction of education includes many facets, the most important of all is innovative teaching for continuous change. The objective of the study is to find out the strength of innovative teaching on the educational change.

\section{Methodology}

It was a cross-sectional retrospective study that has been conducted to find out the effect of innovative teaching on the educational change in higher education institutions. We use cross-sectional study designs when one or more variables are being studied in a given population. This is very effective for creating or forming links and relations (Mann, 2003). Where the results of attentions have already happened before the conduction of study. Retrospective design help the researcher to articulate notions regarding likely and probable relationships (D. J. Bowen et al., 2009). The researcher has chosen the survey method study design because it was serving the purpose of the study in effective manner.

\section{Population}

Population of the study was private and public universities of Lahore. Almost all best public and private universities are working here. Students from all over Punjab attend these universities for better opportunities of tertiary education.

\section{Sample}

Out of this population one public and one private university have been selected as sample of the study. For this purpose "Heterogeneity sampling/ Diversity sampling" methods have been used. As the public university (2) that has been chosen is the biggest university of Punjab where students and teachers from various backgrounds and diversities come from all areas of province. Same is true for the university (1) selected from private sector. This university is catering the students as well as staff almost from all of the Punjab. From both universities the researcher was able to find the different perceptions about innovative teaching and educational change. 
Respondents of the study are selected purposely to have the maximum possible reactions to have possibly all the prospects (Creswell \& Creswell, 2017; Meredith, Gall, \& Borg, 2003; Neuman \& Kreuger, 2003).

\section{Sample Size}

From each university 200 studentsfrom BS, MPhil and $\mathrm{PhD}$ programs and 100 teachers who were teaching these programs were selected as the sample of the study.

\section{Instruments}

Two questionnaires at 5 point Likert scale were developed. The instrument for teacher contained 19 items while that for the students, it was comprised of 31 items. To validate the instrument, experts' opinions were taken. They thankfully gone through questionnaire and each item of the instrument thoroughly. They determine the correctness and suitability of the tool. After adapting their valuable comments and recommendations, the research tool was improved. The same authenticated survey forms were used for the pilot study. The reliability for the teachers' questionnaire was 806 and 940 for the students' instrument.

\section{Data Collection}

Afterwards the conduction of validity and reliability and incorporating important changes, surveys were given personally directly to the chosen respondents of the study. To get retorts from identified sample size, extra instruments were given to the students as well as teachers so that the exact number of responses can be reached.

\section{Data Analysis}

Descriptive and inferential statistics were used to scrutinize the compiled inputs of respondents. The preferences for the reactions were weighted as below:

Strongly agree: 5

$$
\text { Agree: } 4 \quad \text { Neutral: } 3
$$

Disagree: $2 ; \quad$ Strongly Disagree: 1

The $\mathrm{t}$ - test was used to determine the statistically substantial variance in the means of two disparate groups in the study. The t- test is an inferential arithmetical test that calculates even if the means of two sets are statistically differs from each other (Anderson, 2011). 
ANOVA was used to determine the statistically substantial variance in the means of more than two different groups in the study. ANOVA is used very extensively to analyze the unequivocal conclusions (Jaeger, 2008).

\section{Results and Discussion}

Result Reporting

The frequencies and percentages of the variables were computed. All contributors stated are at a $100 \%$ level. The demographics split is shown in the graphs below.

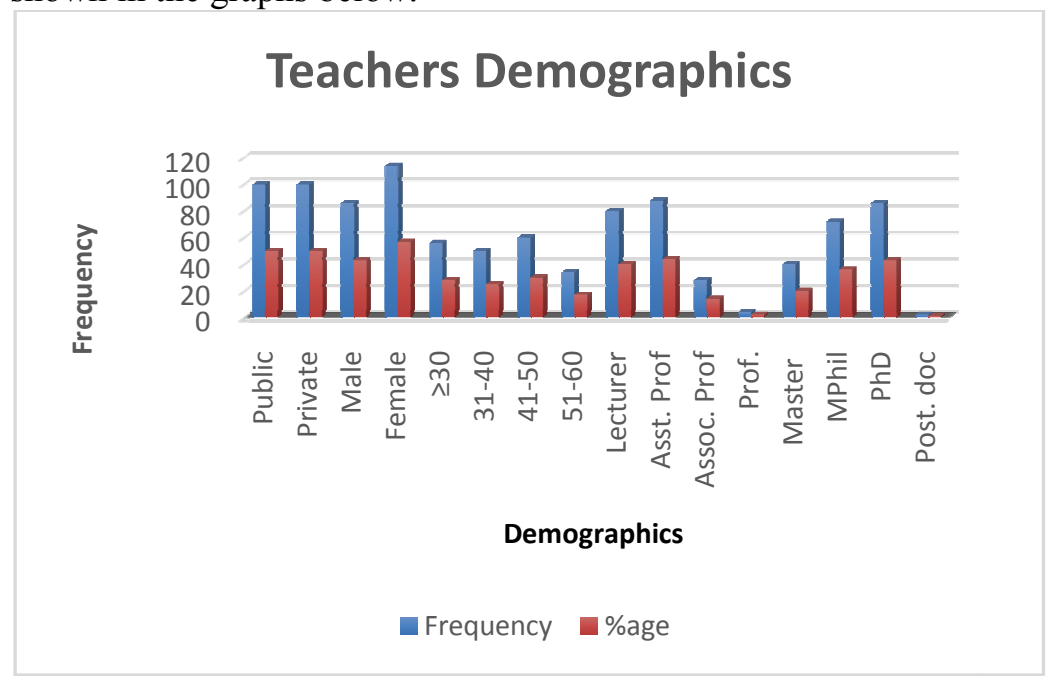

Figure 1: Demographics of University Teachers

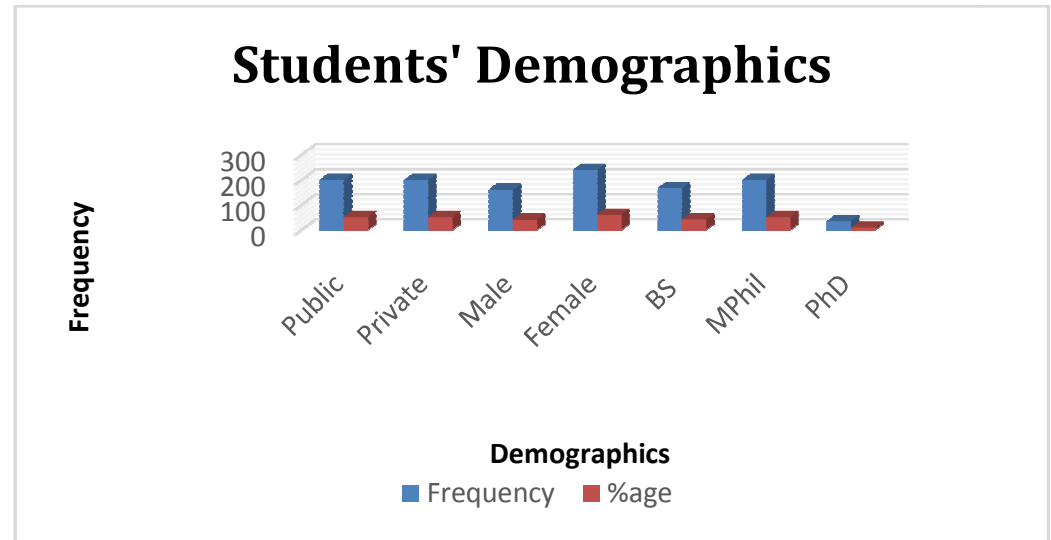

Figure 2: Demographics of University Students 
University type and gender in both cases are stated near the perfection point. In teacher tally table the ages; below 30, 31-40, ad 4150, designations of lecturer, Asst. professors, MPhil, $\mathrm{PhD}$ qualification, and experience from 1-10 informed are at high rate while age from 5160 , designations of associate professor, professors, qualification of master, postdoc and experience from 11-20, more than 20 are at the low rate. In students table of demographics the BS, MPhil qualifications are at higher side while that of $\mathrm{PhD}$ is showing low rate.

Educational Change

1. For educational change tool was distributed among the higher education public/ private teachers being the most vital facilitator of transformation.

Table 1

Descriptive Statistics of Teachers' Items Factors

\begin{tabular}{lccccc}
\hline & $N$ & $M$ & $S D$ & Skewness & Kurtosis \\
\hline Job satisfaction pct. & & & & & \\
& 200 & 78.3000 & 20.98360 & -1.474 .172 & 1.124
\end{tabular}

Personal development

pct.

$\begin{array}{lllll}200 & 85.8000 & 12.45535 & -1.229 .172 & 2.381\end{array}$

Peer group learning pct.

$200 \quad 74.800018 .34175 \quad-.100 \quad .172 \quad-.939$

HM involvement change

pct.

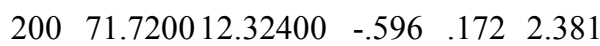

Acceptance for change

pct.

$\begin{array}{lllll}200 & 74.533312 .15496 & -.712 & .172 & 1.620\end{array}$

Valid N (list wise) $\quad 200$

Items were divided into five factors; job satisfaction, personal development, peer group learning, higher management involvement for 
change, and acceptance for change. The cumulated results are given in the table 1 above.

Means have been calculated in percentages for better understanding. The combined results of both sectors show that Mean percentage of personal development is higher (85.8000) and lowest than all is of higher management (HM) involvement for change (71.7200) but that is also above $50 \%$ which is quite significant. The difference between two extreme values shows that the middle values are noteworthy too.

2. The comparison between the perceptions of public and private universities teachers is given in the table below;

Table 2

Difference between Public and Private Universities

\begin{tabular}{|c|c|c|c|c|c|c|}
\hline University teacher & & $\mathrm{N}$ & $\mathrm{M}$ & SD & $t$ & $P$ \\
\hline \multirow[t]{2}{*}{ Job satisfaction pct. } & $\begin{array}{l}1 \\
\text { UMT }\end{array}$ & 100 & 81.9000 & 16.91900 & 2.457 & .015 \\
\hline & $2 \mathrm{PU}$ & 100 & 74.7000 & 23.92982 & 2.457 & .015 \\
\hline \multirow{2}{*}{$\begin{array}{l}\text { Personal } \\
\text { pct. }\end{array}$} & $\begin{array}{l}\text { t1 } \\
\text { UMT }\end{array}$ & 100 & 88.8667 & 7.87415 & 3.584 & .000 \\
\hline & $2 \mathrm{PU}$ & 100 & 82.7333 & 15.19333 & 3.584 & .000 \\
\hline \multirow[t]{2}{*}{ Peer group learning pct. } & $\begin{array}{l}1 \\
\text { UMT }\end{array}$ & 100 & 79.1333 & 17.17814 & 3.430 & .001 \\
\hline & $2 \mathrm{PU}$ & 100 & 70.4667 & 18.52605 & 3.430 & .001 \\
\hline \multirow{2}{*}{$\begin{array}{l}\text { HM involvement change } \\
\text { pct. }\end{array}$} & el & 100 & 76.7200 & 10.55058 & 6.265 & .000 \\
\hline & $2 \mathrm{PU}$ & 100 & 66.7200 & 11.97816 & 6.265 & .000 \\
\hline \multirow{2}{*}{$\begin{array}{l}\text { Acceptance for change } \\
\text { pct. }\end{array}$} & $\begin{array}{l}\text { el } \\
\text { UMT }\end{array}$ & 100 & 80.0000 & 9.92678 & 7.108 & .000 \\
\hline & $2 \mathrm{PU}$ & 100 & 69.0667 & 11.75011 & & .000 \\
\hline
\end{tabular}

The mean percentage values of private sector are significantly higher than public sector. The value of personal development for private is 88.8667 while for public sector it is 82.7333 , which is the highest one. The lowest values are higher management (HM) involvement for change, 76.7200 and 66.7200 for private and public sector respectively. Acceptance for change has a higher value $(80.0000)$ in case of private university but quite a low value (69.0667) in the perception of public sector teachers. All the mean percentages have p-value significant ranging from .000 to .015 . 
Table 3

Difference in the Values on the Basis of Gender

\begin{tabular}{|c|c|c|c|c|c|c|c|}
\hline \multirow{2}{*}{\multicolumn{2}{|c|}{ University teacher }} & \multirow[b]{2}{*}{ Gender } & \multirow[b]{2}{*}{$\mathrm{N}$} & \multirow[b]{2}{*}{ Mean } & \multicolumn{2}{|l|}{ Std. } & \multirow[t]{2}{*}{$P$} \\
\hline & & & & & Deviation & $T$ & \\
\hline \multirow[t]{10}{*}{$1 \mathrm{UM}$} & Job satisfaction pct. & 1 Male & 46 & 88.2609 & 10.60489 & 3.684 & .000 \\
\hline & & 2 Female & 54 & 76.4815 & 19.34370 & 3.847 & .000 \\
\hline & Personal developmen & t1 Male & 46 & 89.8551 & 7.40225 & 1.161 & .249 \\
\hline & pct. & 2 Female & 54 & 88.0247 & 8.22938 & 1.171 & .245 \\
\hline & Peer group learnin & g1 Male & 46 & 77.3913 & 12.68640 & -.935 & .352 \\
\hline & pct. & 2 Female & 54 & 80.6173 & 20.24042 & -.969 & .335 \\
\hline & involvemen & t1 Male & 46 & 77.3913 & 11.53830 & .585 & .560 \\
\hline & change pct. & 2 Female & 54 & 76.1481 & 9.70393 & .577 & .565 \\
\hline & Acceptance for chang & e1 Male & 46 & 82.4638 & 9.59513 & 2.342 & .021 \\
\hline & pct. & 2 Female & 54 & 77.9012 & 9.80515 & 2.346 & .021 \\
\hline \multirow[t]{10}{*}{$2 \mathrm{PU}$} & Job satisfaction pct. & 1 Male & 40 & 83.5000 & 17.32791 & 3.133 & .002 \\
\hline & & 2 Female & 60 & 68.8333 & 25.97859 & 3.387 & .001 \\
\hline & Personal developmen & t1 1 Male & 40 & 80.3333 & 15.31809 & -1.294 & .199 \\
\hline & pct. & 2 Female & 60 & 84.3333 & 15.02415 & -1.289 & .201 \\
\hline & Peer group learnin & g1 Male & 40 & 63.3333 & 13.58732 & -3.297 & .001 \\
\hline & pct. & 2 Female & 60 & 75.2222 & 19.90908 & -3.549 & .001 \\
\hline & involvemen & t1 Male & 40 & 59.8000 & 14.40655 & -5.330 & .000 \\
\hline & change pct. & 2 Female & 60 & 71.3333 & 7.03181 & -4.703 & .000 \\
\hline & Acceptance for chang & e1 Male & 40 & 67.6667 & 15.02515 & -.973 & .333 \\
\hline & pct. & 2 Female & 60 & 70.0000 & 8.95690 & -.883 & .381 \\
\hline
\end{tabular}

On the basis of gender, difference in opinions of private university teachers is significant in case of job satisfaction and acceptance for change but insignificant in case of personal development, peer group learning, and higher management involvement for change. Male and female tutors have the same perception in these cases. On the other hand, the values of public university male/female educators are substantial in factors of job satisfaction, peer group learning, and higher management involvement for change but insignificant personal development and acceptance for change. Overall percentage mean values of independent institution is on higher side as compare to government one (Table 3) 
2. To see the differences on the basis of age, designation, and qualification, of tertiary instructors ANOVA was applied. See the table 4 below;

Table 4

Difference in the Values on the Basis of Age, Designation, and Qualification

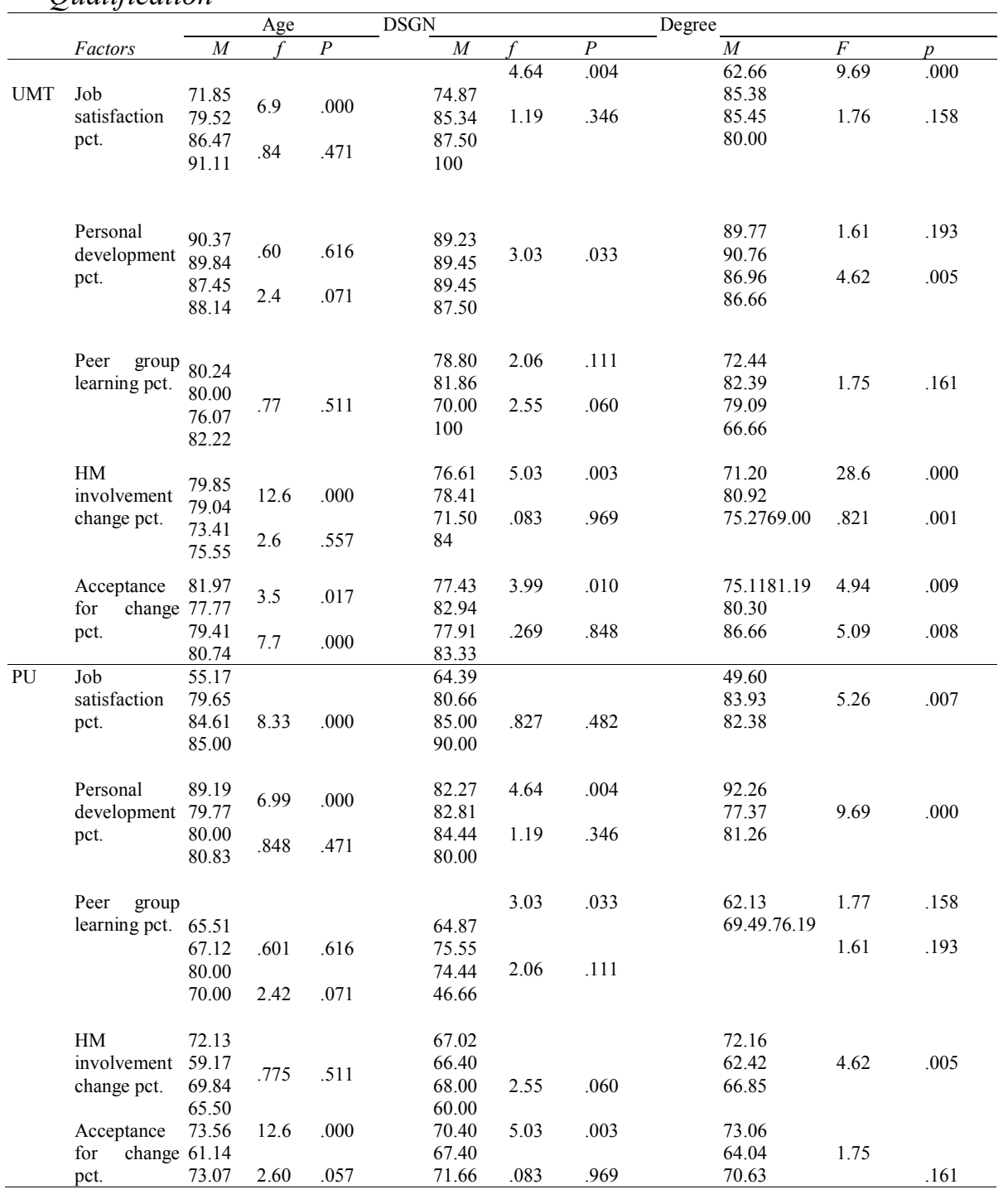


68.75 63.33

Although the values of private sector are higher than the public one yet the trends are almost same. For example job satisfaction and personal development are increasing with the increase in age. While the values are on the descending order in cases of higher management involvement and acceptance for change and are significant in the cases mentioned but are insignificant for peer group learning. If we see the change in perceptions of teachers with respect to designation, except personal development which is on decreasing side with the increase in designation, all other factor are showing increase with elevation in title. The perceptions are moving upward in all factors except higher management involvement in case of increase in the educator's personal qualifications. Same results can be seen with the change in experience. 4. In $20^{\text {th }}$ item the teachers were given the options of different methods of teaching, from conventional to innovative. Teachers were free to opt for as many as options they want.

Table 5

Teachers' Selection of Teaching Methods

\begin{tabular}{ll}
\hline \multicolumn{1}{c}{ Methods } & Responses \\
\hline Formal teaching activities & 72 \\
Informal discussions with students & 36 \\
Formal teacher training activities & 44 \\
Discussing teaching related issues with colleagues & 68 \\
Observe other teachers' teaching & 8 \\
\hline
\end{tabular}

The table 5 shows the responses of teachers. Maximum teachers are with the formal teaching activities and formal teacher training activities, which clearly express their disagreement with adoption of new innovative methods of instruction.

\section{Innovative Teaching}

Improvement in teaching methods in other words innovative teaching, supported by literature review, standing at the most important step of change ladder. How much the university teachers are involve in it, to find the answer of this question, a second questionnaire was circulated among students of those programs which were being taught by the respondent teachers of the study. The results are as under: 
Table 6

Descriptive Statistics of Students' Items Factors

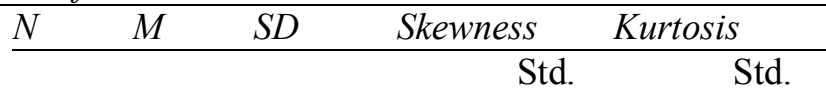

StatisticStatisticStatistic StatisticError StatisticError

\begin{tabular}{lccccc}
\hline $\begin{array}{l}\text { Teaching } \\
\text { preparation pct. }\end{array}$ & 400 & $67.880014 .58071-.463$ & .122 & .652 & .243 \\
$\begin{array}{l}\text { Teaching } \\
\text { strategies pct. }\end{array}$ & 400 & $68.290911 .95993-.174$ & .122 & 1.043 & .243 \\
$\begin{array}{l}\text { Learning } \\
\text { environment pct. }\end{array}$ & 400 & $67.265012 .62570-.111$ & .122 & .806 & .243 \\
$\begin{array}{l}\text { Assessment } \\
\text { techniques pct. }\end{array}$ & 400 & $66.087514 .50537-.265$ & .122 & -.391 & .243 \\
\begin{tabular}{l} 
Valid N (list wise) 400 \\
\hline
\end{tabular} & & & & \\
\hline
\end{tabular}

1. Items were divided into five factors; teaching preparation, teaching strategies, learning environment, and assessment techniques. The combined results of both universities are given in table 6 .

Mean percentage values of all the factors are ranging from $66 \%$ to $68 \%$. The difference between the extremes is not too much and all the values are more than average but are not as high as the values of educational change. This shows that the teachers are not using innovative methods frequently and are still involve in conventional methods of teaching.

2. University wise difference in the opinions of students was calculated on the basis of gender, as shown in table 7.

Table 7

Difference of Opinion on the Basis of Gender

\begin{tabular}{|c|c|c|c|c|c|c|c|}
\hline & Factors & $\begin{array}{l}\text { University } \\
\text { students }\end{array}$ & $N$ & $M$ & $S D$ & $t$ & $p$ \\
\hline \multirow[t]{8}{*}{$1 \mathrm{UMT}$} & Teaching & 1 Male & 80 & 73.4000 & 13.45748 & 670 & .503 \\
\hline & preparation pct. & 2 Female & 120 & 71.9333 & 16.19199 & .695 & .488 \\
\hline & Teaching & 1 Male & 80 & 72.4545 & 14.47942 & .674 & .501 \\
\hline & strategies pct. & 2 Female & 120 & 70.9697 & 15.75550 & .686 & .494 \\
\hline & Learning & 1 Male & 80 & 71.8500 & 13.44384 & 227 & .820 \\
\hline & environment pct. & 2 Female & 120 & 71.3667 & 15.52874 & .234 & .815 \\
\hline & Assessment & 1 Male & 80 & 71.2500 & 13.81386 & 1.355 & .177 \\
\hline & techniques pct. & 2 Female & 120 & 68.2500 & 16.26526 & 1.400 & .163 \\
\hline \multirow[t]{8}{*}{$2 \mathrm{PU}$} & Teaching & 1 Male & 80 & 60.5000 & 13.86189 & -2.588 & .010 \\
\hline & preparation pct. & 2 Female & 120 & 65.0667 & 11.00934 & -2.472 & .015 \\
\hline & Teaching & 1 Male & 80 & 64.9773 & 4.59916 & -.082 & .935 \\
\hline & strategies pct. & 2 Female & 120 & 65.0455 & 6.42268 & -.087 & .930 \\
\hline & Learning & 1 Male & 80 & 62.1750 & 8.96798 & -1.126 & .261 \\
\hline & environment pct. & 2 Female & 120 & 63.5000 & 7.56040 & -1.089 & .278 \\
\hline & Assessment & 1 Male & 80 & 63.8750 & 13.87044 & 1.040 & .299 \\
\hline & techniques pct. & 2 Female & 120 & 61.9583 & 11.97504 & 1.010 & .314 \\
\hline
\end{tabular}


The values of all the factors of innovative teaching are higher for private university as equate to public university but have low percentage values than educational change. On the basis of gender the private institution male student percentage values are on the higher side (71 to 73) than female students (68 to 71) while in case of public sector it's otherwise; for male (60 to 63) and for female (61 to 65).

3. University wise difference in the opinions of students was calculated on the basis of qualifications as shown in table 8 .

Table 8

Difference of Opinions on the Basis of Qualification

\begin{tabular}{|c|c|c|c|c|c|c|c|}
\hline \multicolumn{8}{|c|}{ Factors } \\
\hline \multicolumn{3}{|c|}{ University students } & $N$ & $M$ & $S D$ & $t$ & $p$ \\
\hline \multicolumn{3}{|c|}{1 UMT Teaching preparation1 BS } & 86 & 67.9070 & 13.62319 & 7.785 & .001 \\
\hline \multirow{3}{*}{\multicolumn{2}{|c|}{ pct. }} & 2 MS/MPhil & 100 & 75.6000 & 12.74458 & & \\
\hline & & $3 \mathrm{PhD}$ & 14 & 78.8571 & 28.30291 & & \\
\hline & & Total & 200 & 72.5200 & 15.13921 & 12.233 & .000 \\
\hline \multirow{4}{*}{\multicolumn{2}{|c|}{$\begin{array}{l}\text { Teaching } \\
\text { pct. }\end{array}$}} & s1 BS & 86 & 65.7505 & 13.32839 & & \\
\hline & & 2 MS/MPhil & 100 & 76.0364 & 13.45147 & & \\
\hline & & $3 \mathrm{PhD}$ & 14 & 75.3247 & 24.94713 & 11.191 & .000 \\
\hline & & Total & 200 & 71.5636 & 15.23823 & & \\
\hline & \multirow{2}{*}{$\begin{array}{l}\text { Learning } \\
\text { environment pct. }\end{array}$} & $1 \mathrm{BS}$ & 86 & 66.1860 & 12.59553 & & \\
\hline & & 2 MS/MPhil & 100 & 75.8000 & 12.65709 & 14.468 & .000 \\
\hline & \multirow{6}{*}{$\begin{array}{l}\text { Assessment } \\
\text { techniques pct. }\end{array}$} & $3 \mathrm{PhD}$ & 14 & 74.2857 & 26.68168 & & \\
\hline & & Total & 200 & 71.5600 & 14.69716 & & \\
\hline & & $1 \mathrm{BS}$ & 86 & 63.1395 & 13.97575 & 3.367 & .036 \\
\hline & & 2 MS/MPhil & 100 & 74.1000 & 14.13106 & & \\
\hline & & $3 \mathrm{PhD}$ & 14 & 75.0000 & 18.81080 & & \\
\hline & & Total & 200 & 69.4500 & 15.36646 & .272 & .762 \\
\hline \multirow[t]{16}{*}{$2 \mathrm{PU}$} & \multicolumn{2}{|c|}{ Teaching preparation1 BS } & 80 & 60.5000 & 13.86189 & & \\
\hline & \multirow[t]{3}{*}{ pct. } & 2 MS/MPhil & 100 & 65.2000 & 11.11919 & & \\
\hline & & $3 \mathrm{PhD}$ & 20 & 64.4000 & 10.69383 & 2.069 & .129 \\
\hline & & Total & 200 & 63.2400 & 12.40126 & & \\
\hline & \multirow{4}{*}{$\begin{array}{l}\text { Teaching } \\
\text { pct. }\end{array}$} & s1 BS & 80 & 64.9773 & 4.59916 & & \\
\hline & & 2 MS/MPhil & 100 & 65.2182 & 6.50007 & .775 & .462 \\
\hline & & $3 \mathrm{PhD}$ & 20 & 64.1818 & 6.10478 & & \\
\hline & & Total & 200 & 65.0182 & 5.75029 & & \\
\hline & \multirow{4}{*}{$\begin{array}{l}\text { Learning } \\
\text { environment pct. }\end{array}$} & $1 \mathrm{BS}$ & 80 & 62.1750 & 8.96798 & 7.785 & .001 \\
\hline & & 2 MS/MPhil & 100 & 64.0600 & 7.55561 & & \\
\hline & & $3 \mathrm{PhD}$ & 20 & 60.7000 & 7.11633 & & \\
\hline & & Total & 200 & 62.9700 & 8.15670 & 12.233 & .000 \\
\hline & \multirow{4}{*}{$\begin{array}{l}\text { Assessment } \\
\text { techniques pct. }\end{array}$} & $1 \mathrm{BS}$ & 80 & 63.8750 & 13.87044 & & \\
\hline & & 2 MS/MPhil & 100 & 61.6000 & 12.12061 & & \\
\hline & & $3 \mathrm{PhD}$ & 20 & 63.7500 & 11.34101 & 11.191 & .000 \\
\hline & & Total & 200 & 62.7250 & 12.76771 & & \\
\hline
\end{tabular}


On the basis of qualification again the individual factor percentage values of private university are on higher side than the public one. On the other hand the values of private students are increasing as the qualification are increasing (BS to $\mathrm{PhD}$ ) while in instance of public students these values are on decreasing side with increase of qualification except in two cases, teaching strategies, and assessment techniques, where the values of $\mathrm{BS}$ and $\mathrm{PhD}$ students have very minute difference.

\section{Discussion}

The results shows that teachers are very much interested in their personal development and this interest is increasing with age, qualification but decreasing with advancement in designation. This may be because when the teachers are at junior level, they think they need professional development for their career and the increase in designation is due to progress in their qualification and development so this requirement becomes less important for them.

High rank teachers of both sectors are agreed that the involvement of higher management is not satisfactory or significant. They have not shown satisfaction in the vital role of top management or leadership for employing modification in education system. It is an open that change starts from top. As per the Fullan and Kotter model of change, this involvement is very important. It has been acknowledged extensively that the role of leadership is crucial for the successful implementation of change process (Levy, 2018).

The acceptance of change is stronger in private institution. The teachers in non- government university showed acceptance for the change while government institution did not show much acceptance for the change. Researches have proved that change cannot be brought without the agreement of all the stakeholders. It is a mutual endeavor and it needs resilient transmission of message (McGrath, 2017). Teachers of both sides have not shown agreement, peer group learning, which is an important innovative method of learning and change.

Students did not show covenant on the practices of innovative teaching practices in the classroom. Although the mean values were significant but little above than the middle values.

These opinions improve with the increase in the qualification of students. Male students in independent stratum and female students in public category a little more agree than the opposite gender about innovative teaching in the classroom but that difference is very little, in some cases almost negligible. Students perceptions seems quite accurate 
as in the $20^{\text {th }}$ item regarding instructional approaches, the retorts of instructors are also more in the favor of formal teaching activities.

\section{Conclusion}

It is not a hidden secret that modification in the current practices of study are fixated with the students learning as outcome of education process. As now, we ourselves, cannot rely on what we have experienced or have thoughts because every day is a new day and change is a permanent phenomenon (Taylor, 2017). In education, alteration or modification or change is very complex task to be taken on. It is mainly based on how teachers are developing their instructions and in the result what are the students' learning outcomes. That is why the focus of study was on innovative teaching as a vital component educational change. After conducting this study and other studies on teaching of modern time, I can safely say that if scholars' education is the centerpiece of transition then instructors have the significant characters in this change. So one can believe that learners erudition and facilitators advancement are interlinked with each other. One cannot be achieved without the other. Change cannot be impeccable if one is missing. Students' development is based on how much teachers are transforming their practices according to the current scenario and future demand. 


\section{References}

Anderson, T. W. (2011). The statistical analysis of time series (19): John Wiley \& Sons.

Ballantine, J. H., Hammack, F. M., \& Stuber, J. (2017). The sociology of education: A systematic analysis: Routledge.

Bates, A. W., \& Poole, G. (2003). Effective Teaching with Technology in Higher Education: Foundations for Success: ERIC.

Bell, D., \& Ritchie, R. (1999). Towards effective subject leadership in the primary school: McGraw-Hill Education (UK).

Betts, G., Kapushion, B., \& Carey, R. J. (2016). The autonomous learner model Giftedness and Talent in the 21st Century (201-220): Springer.

Bowen, sD. J., Kreuter, M., Spring, B., Cofta-Woerpel, L., Linnan, L., Weiner, D., Fabrizio, C. (2009). How we design feasibility studies. American journal of preventive medicine, 36(5), 452-457.

Bowen, H. (2018). Investment in learning: The individual and social value of American higher education: Routledge.

Carlopio, J. (1998). Implementation: Making workplace innovation and technical change happen: Synergy Books International.

Carnoy, M., \& Rhoten, D. (2002). What does globalization mean for educational change? A comparative approach. Comparative education review, 46(1), 1-9.

Christensen, C. M., Raynor, M. E., \& McDonald, R. (2016). What is disruptive Innovation. The Encyclopedia of Human-Computer Interaction, 2.

Cincera, J., Biberhofer, P., Binka, B., Boman, J., Mindt, L., \& Rieckmann, M. (2018). Designing a sustainability-driven entrepreneurship curriculum as a social learning process: A case study from an international knowledge alliance project. Journal of Cleaner Production, 172, 4357-4366. 
Collins, A., \& Halverson, R. (2018). Rethinking education in the age of technology: The digital revolution and schooling in America: Teachers College Press.

Creswell, J. W., \& Creswell, J. D. (2017). Research design: Qualitative, quantitative, and mixed methods approaches: Sage publications.

Culp, B. D. (2016). Essential Knowledge for Teachers: Truths to Energize, Excite, and Engage Today's Teachers: Rowman \& Littlefield.

Evers, W. J., Brouwers, A., \& Tomic, W. (2002). Burnout and self $\square$ efficacy: A study on teachers' beliefs when implementing an innovative educational system in the Netherlands. British Journal of Educational Psychology, 72(2), 227-243.

Fadeeva, Z., \& Mochizuki, Y. (2010). Higher education for today and tomorrow: university appraisal for diversity, innovation and change towards sustainable development. Sustainability Science, 5(2), 249256.

Freeman, S., Eddy, S. L., McDonough, M., Smith, M. K., Okoroafor, N., Jordt, H., \& Wenderoth, M. P. (2014). Active learning increases student performance in science, engineering, and mathematics. Proceedings of the National Academy of Sciences, 111(23), 84108415 .

Fullan, M. (2001). The new meaning of educational change: Routledge.

Gargiulo, R. M., \& Metcalf, D. (2017). Teaching in Today s Inclusive Classrooms: A Universal Design for Learning Approach: Nelson Education.

Hamburg, I., \& Bucksch, S. (2017). Inclusive education and digital social innovation. Advances in social sciences research journal, 4(5).

Hargreaves, A., Lieberman, A., Fullan, M., \& Hopkins, D. (2014). International handbook of educational change: Part two (5): Springer.

Healey, M., Flint, A., \& Harrington, K. (2016). Students as partners: Reflections on a conceptual model. Teaching \& Learning Inquiry, $4(2), 1-13$. 
Holmes, N., Wieman, C. E., \& Bonn, D. (2015). Teaching critical thinking. Proceedings of the National Academy of Sciences, 112(36), 11199-11204.

Jaeger, T. F. (2008). Categorical data analysis: Away from ANOVAs (transformation or not) and towards logit mixed models. Journal of memory and language, 59(4), 434-446.

Kegan, R. (2018). What "form" transforms?: A constructivedevelopmental approach to transformative learning Contemporary theories of learning (29-45): Routledge.

Levy, M. (2018). Change Management Serving Knowledge Management and Organizational Development: Reflections and Review Global Practices in Knowledge Management for Societal and Organizational Development (256-270): IGI Global.

Lozano, R., Ceulemans, K., Alonso-Almeida, M., Huisingh, D., Lozano, F. J., Waas, T., Hugé, J. (2015). A review of commitment and implementation of sustainable development in higher education: results from a worldwide survey. Journal of Cleaner Production, $108,1-18$

Mann, C. (2003). Observational research methods. Research design II: cohort, cross sectional, and case-control studies. Emergency medicine journal, 20(1), 54-60.

Matthews, K. E., Cook-Sather, A., \& Healey, M. (2018). Connecting learning, teaching, and research through student-staff partnerships: Toward universities as egalitarian learning communities.

McGrath, C. (2017). What we talk about when we talk about change: a study of change practice and change agency in higher education.

Meredith, W. R. B., Gall, J. P., \& Borg, W. R. (2003). Education Research. An Introduction (seventh edition). United States of America.

Muijs, D., \& Reynolds, D. (2017). Effective teaching: Evidence and practice: Sage.

Myers, C. E. (2017). Elements of Change. Perspectives In Learning, $16(1), 4$. 
Neuman, W. L., \& Kreuger, L. (2003). Social work research methods: Qualitative and quantitative approaches: Allyn and Bacon.

Nobes, C., Parker, R. B., \& Parker, R. H. (2008). Comparative international accounting: Pearson Education.

Reaburn, P., \& McDonald, J. (2017). Creating and facilitating communities of practice in higher education: Theory to practice in a Regional Australian University Communities of Practice (pp. 121150): Springer.

Robbins, S. P., \& De Cenzo, D. A. (2001). Fundamentals of Management E-Business Updated Edition: Prentice Hall.

Schön, D. A. (2017). The reflective practitioner: How professionals think in action: Routledge.

Schwab, K. (2017). The fourth industrial revolution: Crown Business.

Serdyukov, P. (2017). Innovation in education: what works, what doesn't, and what to do about it? Journal of Research in Innovative Teaching \& Learning, 10(1), 4-33.

Talbot, R., Doughty, L., Nasim, A., Hartley, L., \& Le, P. (2016). Theoretically Framing a Complex Phenomenon: Student Success in Large Enrollment Active Learning Courses. pdf.

Taylor, E. W. (2017). Transformative learning theory Transformative Learning Meets Bildung (17-29): Springer.

Wlodkowski, R. J., \& Ginsberg, M. B. (2017). Enhancing adult motivation to learn: A comprehensive guide for teaching all adults: John Wiley \& Sons.

\section{Citation of this Article:}

Naz, F., \& Murad, H. S. (2019). Innovative teaching: an effective ingredient for educational change at university level. Pakistan Journal of Education, 36(2), 115-135 